\title{
Getting to the Heart of It All: An Analysis of Due Process in Interscholastic Athletics
}

\section{W. Andrew Czekanski, Amanda Siegrist, and Thomas Aicher ${ }^{*}$}

\begin{abstract}
Based on authority of the Fourteenth Amendment to the Constitution, a person is entitled to procedural due process protections by the state prior to the deprivation of any life, liberty, or property interest to ensure a just outcome. While many people assert interscholastic athletics are an important part of a student's overall education, courts have been reluctant to accept this argument. The purpose of this article is to examine how past legal precedent applies to the current structure and purpose of interscholastic sports. To achieve this, a single state athletic association (i.e., the Ohio High School Athletic Association) was examined as well as the state's accompanying school districts. Mission statements, structure, and modes of operation were examined in-depth through surveying high schools and performing a content analysis of state bylaws. Results revealed the use of pay-to-play, affording student-athletes academic credit for participation, and current mission statements and bylaws may be increasing the liability of school districts.
\end{abstract}

Keywords: interscholastic athletics, Fourteenth Amendment, Ohio High School Athletic Association

\section{Introduction}

The growth of high school sports participation has been well documented and publicized over the decades with the National Federation of State High School Associations (NFHS) continually reporting a record number of participants. In the 2016-2017 school year alone, an all-time high of 7,963,535 students participated in high school sports, marking the 28th straight year participation totals rose (NFHS, 2017). The rise in participation, marked with an increase in dependence on the courts to solve legal disputes, has created an environment in which student-athletes and their parents often turn to the legal system to get justice (Green, 2015). Such cases smatter the local and national news and include but are not limited to issues of concussion protocol, hazing, sexual harassment, and Title IX (Green, 2015). Demonstrating the strength of the high school sport

\footnotetext{
* W. Andrew Czekanski, PhD, is an assistant professor in the Department of Recreation and Sport Management at Coastal Carolina University; email: wczekansk@coastal.edu. Amanda Siegrist, $\mathrm{JD}$, is an assistant professor and program director of the undergraduate law program at Thomas More University; email: siegria@thomasmore.edu. Thomas Aicher, $\mathrm{PhD}$, is an assistant professor of sport management in the College of Business at the University of Colorado, Colorado Springs; email: aicherts@ucmail.uc.edu.
} 
and law intersection, Green (2017) highlighted over 20 cases filed in 2016 centered on high school sports participation and various legal issues. For example, in one such case

a suit was filed in Montana, Back v. Belt Valley School District, seeking \$20 million from the district, its athletic director, its football coaches and an athletic trainer for allegedly disregarding their state concussion law by prematurely returning a concussed player to action who then suffered a second head injury that rendered him a quadriplegic. (Green, 2017, para. 9)

Thus, with an ever-increasing number of participants and the evolving intersection between sport and the law, student-athlete management should be an increasing priority for high school administrators. As Green (2015) notes in an official NFHS publication,

In a society and an era where the trend is toward individuals with any grievance whatsoever ... immediately pursuing litigation as their preferred recourse, risk management in the context of minimizing legal exposure has become an inescapable part of the job description for school and athletics personnel. It is imperative that a wide range of school officials - superintendents, principals, athletics directors, coaches, athletic trainers, event supervisors and other athletics personnel - be aware of and familiar with the details of the ever-increasing scope of legal issues related to school athletics programs. (para. 1)

One such legal issue highlighted by the NFHS is that of the constitutional rights of student-athletes. Green (2015) noted such claims are the fourth most relevant concern for school administrators. More specifically, lawsuits citing violations of freedom of speech (First Amendment), illegal search and seizure (Fourth Amendment), equal protection (Fourteenth Amendment), and right to due process (Fifth and Fourteenth Amendments) have become increasingly common in recent history (Green, 2015, 2016). While many of these constitutional claims are complex and seemingly unavoidable given the current sport and legal environment, those claims centered on a violation of the right to due process might be more easily evaded using various risk management tactics.

Before risk management tactics are put in place, though, high school athletic associations and high schools themselves must first understand the basic elements of the legal arguments they face. Siegrist, Czekanski, and Silver (2016) do well to outline such arguments of due process claims, noting the legal decision is often dependent upon the court's view of interscholastic athletics as part of the total educational process. Though most scholars and practitioners rely heavily on the Taylor v. Enumclaw School District decision in claiming extracurricular activities (e.g., athletics) are not a part of the educational process, other decisions (e.g., Flordia High School Activities Association v. Bryant; Duffley v. New Hampshire Interscholastic Athletic Association, Inc.) offer contradictory rulings. Like the Taylor decision, these cases have all been tried at the state level. As such, the finding in Flordia and Duffley, (i.e., that interscholastic athletics is a part of the educational process and thus student-athletes are entitled to due process) 
serve as the legal precedent in specific states but not at the national level. Thus, it is important that actors involved in interscholastic athletics assess their legal arguments as a whole but also in relation to the state in which they live.

After an understanding of the legal arguments for the affording of due process to student-athletes is reached, athletic associations and high schools alike should then move to evaluate their current policies and procedures to see what legal liability they face (Siegrist et al., 2016). In this manner, policies and produces should be examined on a case-by-case basis to determine how they relate to the current legal precedent in the given state. Furthermore, athletic associations, school districts, and schools should review their mission statements to evaluate how they speak of education and sports. If determinations are made that the policies, procedures, or mission statements open the institutions to due process claims, changes should be made or steps should be taken to reduce the potential risk.

While the work of Green $(2015,2016)$ does well to highlight the liability high school athletic associations and athletic departments face in regards to constitutional claims of due process violations, and Siegrist et al. (2016) provide an outline of the legal arguments of such claims, scholars have fallen short in providing a complete assessment of the level of the threat on a state-by-state basis. More specifically, an in-depth dissection of the due process issues in relation to the current operations, policies, and procedures of state high school athletic departments and specific high schools is lacking. Without such analysis, the call to athletic associations and high schools for action to address issues remains overly broad and non-specific. As such, a gap exists between the theoretical discussion and practical application.

The goal of the piece was to address this gap in understanding, through a dissection of a single state high school athletic association and the state's schools. In this manner, the paper first focuses on analyzing the legal arguments behind procedural due process claims. The work then moves to examine a single state's high school athletic association and the accompanying schools to determine if their policies, produces, and/or operations unduly opened them to legal risks tied to due process. Finally, the piece concludes with a discussion of recommendations for practitioners (e.g., high school administrators, coaches, high school athletic associations) to manage the risk of potential due process lawsuits moving forward.

\section{Review of Literature}

\section{Procedural Due Process Defined}

The Fourteenth Amendment of the United States Constitution affords procedural due process protections to a person prior to the deprivation of a life, liberty, or property interest by the state or any of its state actors (U.S. Const. amend. XIV). Public educational institutions at the elementary, middle, and high school levels qualify as state actors because they are established and funded by the local and state government. Thus, as state actors, these educational institutions must abide by the Constitution. The Due Process Clause of the Fourteenth Amendment 
aims to ensure fairness in procedures to prevent the wrongful deprivation of an interest, as well as to allow people to feel as if the government, or a state actor, has heard their side of the story to ensure fair treatment (Linder, 2015). For example, prior to being suspended from school for more than a trivial period (i.e., 10 days or more), students are entitled to procedural due process (Goss v. Lopez, 1975).

In terms of the law, a property interest is established to be a "governmentally created expectation" as defined by the Supreme Court (Goss v. Lopez, 1975). The Supreme Court in Board of Regents v. Roth (1972) said the following of property interests:

To have a property interest in a benefit, a person clearly must have more than an abstract need or desire for it. He must have more than a unilateral expectation of it. He must, instead, have a legitimate claim of entitlement to it. It is a purpose of the ancient institution of property to protect those claims upon which people rely in their daily lives, reliance that must not be arbitrarily undermined. It is a purpose of the constitutional right to a hearing to provide an opportunity for a person to vindicate those claims. (p. 572)

\section{Total Educational Process Defined}

The term "total education process" was coined in the 1975 Goss v. Lopez ruling. A review of the case reveals an incident in which a public high school student (i.e., Goss) was suspended from school for 10 days. Claiming a violation of his right to due process, Goss filed suit, stating a suspension without a hearing was unconstitutional. Appealed all the way to the United States Supreme Court, a 5-4 decision was issued in favor of Goss. Justice White noted in the majority opinion that because a person is required by state laws to attend school up until a certain age, and therefore has a governmentally created expectation, a property interest exists in regards to all activities included in the educational process.

Justice White added that the government is not only requiring, but also creating a "legitimate claim of entitlement" to an individual's primary and secondary education. As a result, a property interest exists and, consequently, academic institutions are required to afford students procedural due process before depriving them of such for more than a minimal amount of time. In determining what qualifies as this educational property interest within primary and secondary education, the court provided a broad definition, noting all activities encompassing the "total educational process" were included (Goss v. Lopez, 1975).

Examined deeper, the "total educational process" refers to all formalized school activities contributing to the edification of youth, including discretionary decisions of school personnel (Goss v. Lopez, 1975). These activities include but are not limited to: "how to grade the student's work, whether a student passes or fails a course ... (and) whether he may be excluded from interscholastic athletics or other extracurricular activities ..." (Goss v. Lopez, 1975, End footnotes III). Furthermore, in the decision issued in Albach v. Odle (1976) the judge noted, "The educational process is a broad and comprehensive concept with a variable and indefinite meaning" (p. 984). 


\section{Total Educational Process in Sport}

The very purpose of procedural due process is to prevent arbitrary and inconsistent outcomes by state actors. In discussing discipline outcomes related to a student's education, Justice White stated:

The student's interest is to avoid unfair or mistaken exclusion from the educational process, with all of its unfortunate consequences. Disciplinarians, although proceeding in utmost good faith, frequently act on the reports and advice of others; and the controlling facts and the nature of the conduct under challenge are often disputed. (Goss v. Lopez, 1975, p. 581)

Due to the fact interscholastic athletics play a vital role in the education of those who participate (Coleman, 1961; Yeung, 2015), disciplinary procedures should arguably follow the Supreme Court's decision and be governed in a fair and consistent manner. Therefore, at least minimum due process protections should be required when suspending a student from extracurricular activities to ensure the school's decision is not arbitrary. However, the educational process's relation to extracurricular activities, in particular to athletics, has been a point of contention over the years, as a majority of courts hearing the legal issue have held participation in athletics is a privilege and not a right (e.g., Brentwood Academy v. Tenn. Secondary School Athl Assn, 2001; Bruce v. S.C. High School League, 1972; Hamilton v. Tenn. Secondary School Athl Assn, 1976; Morrison, et al., v. Roberts, 1938; Niles v. University Interscholastic League, 1983; Whipple v. Oregon Sch Activities Assn, 1981; Wooten v. Pleasant Hope R-VI School District and Stout, 2000; Zehner v. Central Berkshire Regional School District, 1995).

To dissect the bulk of courts' outlook on this matter, the previously mentioned case of Taylor v. Enumclaw School District (2006) is a relevant and more recently tried example. In Taylor, the Court of Appeals of Washington ruled that when the student was suspended from the team for underage drinking, no violation of the student's due process rights occurred because the student did not possess a property interest in interscholastic athletics (Taylor v. Enumclaw School District, 2006). The student argued that based on the precedent established by the United States Supreme Court in Goss v. Lopez (1975) establishing a property interest in education, his participation on the football team was a part of his "total educational process" and therefore entitled him to procedural due process prior to suspension from athletics. However, the court reasoned that athletics were not a part of the required curriculum of the school and, as such, was not a part of the student's education (Taylor v. Enumclaw School District, 2006).

In spite of the Court of Appeals of Washington's outlook, a claim of a violation of due process may still hold potential weight. For example, if a plaintiff were to reference Justice White's previously noted inclusion of athletics in the Goss (1975) end footnote, it may prove more difficult for a court to overlook the claim that interscholastic sports is not part of the educational process, and thus should be subject to the same constitutional protections afforded students' deprivation of the classroom. 
While not currently the majority view, nor true in recent cases, certain courts in various contexts have validated this claim in the past, which can still prove to be an important persuasive precedent. For example, according to Duffley v. New Hampshire Interscholastic Athletic Association, Inc. (1982), state athletic associations that include the construct of education within their mission statements or bylaws directly tie interscholastic athletics to the educational process. More specifically, within Duffley (1982) the New Hampshire Supreme Court found a high school student-athlete had a right to due process. In the judgment, the court stated, "It is apparent that interscholastic athletics are considered an integral and important element of the educational process in New Hampshire. It follows that the right to participate in them at least rises above that of a mere privilege" (Duffley, 1982, p. 492).

The New Hampshire Supreme Court finding was grounded in the State Department of Education's guidelines claiming, "Pupil activities, including athletics, should be considered a part of the curriculum" (Duffley, 1982, p. 492). Additionally, the state athletic association stated its goal was "to establish the state athletic program as an integral part of the entire school program" (Duffley, 1982, p. 492), thus extending the court's justification of sport as part of the total educational process (Siegrist et al., 2017). As such, this includes instances in which the high school athletic association's and/or State Department of Education's stated purpose is "to promote athletics as a part of education, the argument for athletics' inclusion in the total educational process is greatly strengthened" (Siegrist et al., 2017, p. 12).

Other court cases (e.g., Florida High School Activities Association v. Bryant, 1975; Albach v. Odle, 1976), in addition to Duffley (1982), have also contrasted the findings of Taylor (2006). Viewing interscholastic sports as part of the educational process in specific contexts, these courts have granted high school student-athletes constitutional rights. For example, in Florida High School Activities Association v. Bryant (1975) the court reasoned, "It (interscholastic sports) is an important and vital part ... of his general scholastic and social development and rehabilitation from his prior problems ..." (p. 57).

Furthermore, in Albach v. Odle (1976), the court acknowledged in its judgment, "It (the educational process) is not limited to classroom attendance but includes innumerable separate components, such as participation in athletic activity ... which combine to provide an atmosphere of intellectual and moral advancement" (p. 984). While this and the previously noted minority court decisions date back to the 1970s and ' 80 s, all follow the Supreme Court's decision in Goss (1975). Moreover, reliance on common law as derived from custom and judicial precedent has long been a method used in addition to statutory law within our society. As such, there is a substantial legal argument that high school sports is a part of the total educational process (Siegrist et al., 2017).

\section{Property Interests and Pay-to-Play Interscholastic Athletics}

The vast majority of courts in the past have been reluctant to accept claims of a property interest in athletics, having relied heavily on stare decisis principles. However, due to the changing nature of high school sports, reliance on former 
decisions may now prove to be insufficient, particularly in regards to the essence of what the Supreme Court deems to be a property interest. The Supreme Court has said,

liberty and property are broad and majestic terms ... purposely left to gather meaning from experience ... they relate to the whole domain of social and economic fact, and the statesmen who founded this Nation knew too well that only a stagnant society remains unchanged. (Board of Regents v. Roth, 1972, p. 571)

Thus, it is important to continue to evaluate high school athletic associations and the schools themselves to determine if the evolution of the organization warrants a more current interpretation of these legal concepts.

For example, the current day budgetary restraints of school districts have resulted in more high school administrators and school districts across the country instituting pay-to-play programs. First established in the 1970s, pay-to-play school districts charge students wishing to participate in interscholastic sports (and often other extracurricular activities) a participation fee that helps cover some (or all) of the operating costs (e.g., coach salaries, field maintenance, travel; Brady \& Glier, 2004). Moreover, instead of charging students a monetary amount to participate in a given sport or athletics, some districts ask for "donations" from athletes or "ask" them to sell a set amount of signage and/or sponsorship on behalf of the athletic department (Brady \& Glier, 2004).

These practices of obtaining money directly from participants have grown considerably over the decades (Brady \& Glier, 2004). Scholar Scott Smith noted in 2004, "as education budgets shrink, more and more schools are trying (payto-play) ... It's a national phenomenon" (Brady \& Glier, 2004, para. 9). While no national surveys are available to determine the exact number of school districts who prescribe to a pay-to-play model (Cook, 2012), research done in 2004 found 34 states had at least some districts with a form of pay-to-play (Brady \& Glier, 2004).

Such an evolution in high school sports arguably creates a vested property interest in student-athletes' participation on an athletic team. A property interest includes, among other things, money, goods, and services (Property; property interest, n.d.). The denial of a property interest would thus result from the refusal of a service or good for which a person has paid (Property; property interest, n.d.). It may be argued then that the actions of pay-to-play programs (i.e., paying money for the services of coaching, transportation to and from games, field maintenance, etc.) create a property interest for student-athletes that, in turn, entitles them to the right to due process.

\section{Ohio High School Athletic Association}

The Ohio High School Athletic Association (OHSAA) was founded in 1907 as a "voluntary, unincorporated, not for-profit association of public and private schools" (Burggraf \& Rau, 2017, p. 3). Beginning with just 30 member schools (Hudak, 2017), OHSAA has grown over its $100+$ years to include 821 high schools as of 2017 (Burggraf \& Rau, 2017). This substantial growth has also been reflected in Ohio being ranked fifth in the nation in interscholastic student- 
athlete participation in the 2016-2017 school year with just over 340,000 studentathletes (The National Federation of State High School Associations, 2017).

As the state of Ohio does not regulate high school athletics, OHSAA's primary role is to assume such responsibility (Burggraf \& Rau, 2017). Accordingly, among other things, it is tasked with "establishing and regulating regular season and tournament standards in order for competition to be fair and equitable, administering exceptional interscholastic athletics tournaments, and promoting that interscholastic athletics participation complements a student's educational experience" (About the OHSAA, 2017, para. 3). These roles are reflected in its mission statement, which declares, "The Ohio High School Athletic Association provides educational opportunities for students through participation in interscholastic athletics programs while also providing leadership and support for member school administrators and coaches and contest officials" (About the OHSAA, 2017, para. 1).

While OHSAA does include statements pertaining to its role and the role of sport in a student-athlete's education experience, it goes to great lengths to deny that such roles entitle students to certain legal protections. More specifically, it states that participation in high school sports is a privilege, not a right, citing the 1981 Menke v. Ohio High School Athletic Association court case as justification (About the OHSAA, 2017; Burggraf \& Rau, 2017). In this case, the Court of Appeals of Ohio in Hamilton County stated,

Education is not one of the rights that has been recognized by the Supreme Court as being "fundamental." The rights so recognized include the right to vote, the right of access to and equal treatment in civil and criminal litigation, and the right to migrate, but education is not among them ... Education is a process having a number of components including studies, social and other extracurricular activities and athletics, and as only one of those components, participation in interscholastic athletics, in and of itself, has never been held to be a constitutionally protected civil right.

Accordingly, OHSAA argues that while high school students are entitled to equality of opportunity based on federal laws (e.g., Title IX, American with Disability Act; Burggraf \& Rau, 2017) they are not entitled to protections granted by the Constitution of the United States. "Therefore, school boards and athletic associations have the authority to regulate interscholastic athletics and to establish program and eligibility requirements, so long as any such regulations and requirements comply with state and federal law" (Burggraf \& Rau, 2017, p. 1).

Yet, there is an important distinction between claiming to have a right to participate in interscholastic athletics and a right to procedural due process when a property interest is being deprived. The argument need not be that athletics are a right; indeed, they may remain a privilege. But nonetheless, a property interest is established by a governmentally created expectation. When a student-athlete has earned a spot on an athletic team or a place within an extracurricular program that is provided by a public institution, that expectation is arguably established.

Furthermore, as legal precedent (e.g., Goss v. Lopez, Flordia High School Activities Association v. Bryant, Duffley) and high school sports (e.g., the increase 
in pay-to-play structure, allowing academic credit for interscholastic sports participation) have evolved drastically since 1981, OHSAA and its member schools' reliance on the Menke decision may leave them susceptible to litigation. Accordingly, the time is right to reassess the potential risk of constitutional claims within OHSAA and Ohio high school athletic programs. The current study sought to do just that through examining the potential connection between the total educational process and interscholastic sports in the state of Ohio. Furthermore, it moved to assess the legal liability of one of the top constitutional issues within high school sports (i.e., Fourteenth Amendment Due Process claims) in relation to the policies and procedures of the Ohio high schools. In doing so, the following three research questions were posed:

RQ1: Do the Ohio High School Athletic Association and its associated high schools have an established link between athletic participation and the total educational process?

RQ2: How is the current day pay-to-play structure and its utilization by Ohio high school athletic departments potentially affecting claims of violation of due process?

RQ3: What policies and procedures are in place to potentially mitigate due process litigation?

\section{Method}

\section{Procedures}

To analyze the present day intertwining of interscholastic athletics and academics, and the structural changes to high school athletic department funding, and thus evaluate student-athletes' legal rights to due process, an in-depth examination of a single state athletic association and the accompanying high schools was undertaken. The decision to study a single state was made due to the exploratory nature of the study. That is to say, the researchers wanted to gauge and study indepth the policy and practices of an athletic association and its accompanying high schools to test potential legal liability. As this analysis had yet to be performed, a micro approach was deemed to be the most appropriate means to answer the ascribed legal questions. Accordingly, purposeful sampling was employed and the state of Ohio was chosen for examination. More specifically, the state of Ohio was chosen due to state laws allowing high school student-athletes to receive academic credit for high school sports participation and laws allowing schools to institute pay-to-play athletic programs.

To answer the research questions, a content analysis of the Ohio High School Athletic Association (OHSAA) was first conducted, focusing specifically on the organization's mission statement and bylaws. Next, a survey was developed and emailed to all high school athletic directors in the state of Ohio to gain a greater understanding of how school districts entangle sports and academics and how 
pay-to-play was employed. Email addresses were obtained through each high school's website. When no athletic director email could be found, the school's principal or vice principal was sent the survey. In total, the survey was sent to 640 individuals and 231 usable responses were returned, yielding a $36.1 \%$ response rate. All procedures were in compliance with university institutional review board standards.

\section{Instrument}

The self-created survey contained three distinct sections to measure pay-to-play standards and structure within the school district, policies for assigning academic credit for interscholastic athletics participation, and disciplinary policies and procedures for interscholastic athletics maleficence.

In the first section, participants were asked if their school district employed a pay-to-play structure. Accordingly, participants were asked to select from a list the form(s) of "pay-to-play" employed by their school district (i.e., athletic fees, fundraising, pay-to-play/pay-to-participate, donations, selling of signage, selling of sponsorship, other). Next, they were asked, if they did employ pay-to-play, to identify the structure the pay-to-play takes (i.e., athletic fees, fund raising, pay-to-play, donations, selling of signage, selling of sponsorship). Finally, an open-ended question asked participants who had pay-to-play programs to denote an approximated amount charged to each student-athlete.

Respondents were then asked in the second section if their school district allowed student-athletes to receive high school credit for sports participation. This item was a yes/no question used to assess the frequency of credit-affording policies and to determine if a potential connection between athletics and the total educational process existed.

Finally, athletic directors were posed another yes/no question to determine if the school had a formal disciplinary process (i.e., "Does your school have a formal process to hear athletic disciplinary issues?"). For those institutions that indicated they had a formal disciplinary process, an open-ended question followed asking them to describe the process.

\section{Validity and Reliability}

Upon developing the instrument, it was viewed by two lawyers and two scholars in the field to determine if the ascribed constructs were adequately measured. The lawyers and scholars all had previous experience studying and/or working with the Due Process Clause of the Fourteenth Amendment. Each individual was asked to review the items and make suggestions for any possible changes and to identify any potential omissions. Once all the feedback was received the suggested modifications were analyzed and changes were made. In this manner, the instrument was established to have both content and face validity.

To measure reliability, the researchers examined the written bylaws/policies of 25 of the responding institutions. To determine which 25 institutions to examine for the analysis, systematic random sampling was employed. Within the content analysis, the researchers specifically sought to establish the following; (1) if pay-to-play was used within the school district, and if so, the form it took; 
(2) if academic credit could be granted to students for participation in athletics; and (3) the method of disciplining behavior code of conduct issues. The answer to each item was then cross-checked to the survey responses of the appropriate participant to determine if the respondent accurately answered the survey items. Analysis showed each of the 25 respondents accurately responded to the ascribed items, thus establishing internal consistency reliability.

Finally, to establish the reliability of the OHSAA mission statement and bylaws analysis, two researchers analyzed the data. After all data was analyzed independently, the researchers established inter-coder agreement in the identification and application of the contents (Creswell, 2009). Thus, inter-observer reliability was established. The researchers followed the recommendation of Lincoln and Gupta (1985) to ensure greater dependability and credibility of results.

\section{Analysis}

As a means to answer the prescribed research questions, a mixed-method approach was utilized. Addressing the first research question, OHSAA's mission and bylaws were analyzed independently by two researchers who obtained the information through the organization's website. In performing the analysis, each reviewer sought to identify verbiage linking athletics and the educational process. After each researcher finished identifying terms and phrases connecting sport and education, the research team discussed the identified links, and the legal ramifications were postulated and noted.

To further address RQ1, the survey item inquiring about the affording of academic credit for athletics participation was assessed. Specifically, the total number of school districts that allowed academic credit for athletics participation was counted and the frequency of occurrence was determined. To establish the potential liability of those school districts allowing academic credit, the open-ended qualitative survey responses to the disciplinary policy were evaluated. This also helped answer RQ3. As with OSHAA's bylaws and mission statement, the disciplinary policies were assessed independently by two researchers. First, it was determined whether the school district had a formal disciplinary policy or not. Next, the policies were examined in-depth by two researchers who independently coded the responses as a means to identify overall themes.

Finally, to answer the second research question, the pay-to-play section of the survey was appraised. The researchers first calculated the total number and frequency of school districts using each of the ascribed forms of pay-to-play. Results were also computed to determine the measures of central tendency in relation to the cost of to the student-athlete.

\section{Results}

In relation to the first research question (i.e., "Does the Ohio High School Athletics Association and its associated high schools have an established link between athletic participation and the academic process?"), content analysis of the OHSAA mission statement and bylaws revealed two potential connections between the total education process and interscholastic athletics in the state of Ohio. Beginning with the previously noted mission statement, OHSAA 
claims its goal is to "provides educational opportunities for students through participation in interscholastic athletics programs" (About the OHSAA, 2017, para. 1). Furthermore, OHSAA Bylaw 4 (2017) titled "Student Eligibility" states the athletic competitions within the state are designed to promote "competitive balance and serves the mission and purpose of education-based sports and activities" (p. 39).

In addition to the bylaws and mission statement, results from the survey of Ohio high schools also revealed a potential resounding link between sports and academics. That is, 114 (49.1\%) of the responding schools reported allowing student-athletes to receive some form of academic credit for participating in interscholastic sports.

Moving to address the second research question (i.e., "How is the current day pay-to-play structure and its utilization by Ohio high school athletic departments potentially affecting claims of violation of due process?"), the survey also inquired about the use of pay-to-play. This was done as a means to determine the potential connections between athletics and property interests. As pay-to-play may take multiple forms, athletic directors were asked to identify all manners in which they obtain money from student-athletes. Of the 231 respondents, $110(47.6 \%)$ stated they used "pay-to-play or pay-to-participate programs," 48 $(20.7 \%)$ charged student-athletes "athletic fees," and $181(78.0 \%)$ used some form of mandatory "fundraising" (see Table 1).

Table 1. Frequency Table of Ohio High School's Pay-to-Play Methods

\begin{tabular}{l|c|c}
\hline $\begin{array}{l}\text { Method(s) employed by your school district to gain } \\
\text { money from high school athletic participants. }\end{array}$ & Frequency & Percent \\
\hline Athletic fees & 183 & 79.2 \\
\hline Fundraising & 181 & 78.0 \\
\hline Pay-to-play/ pay-to-participate fees & 110 & 47.4 \\
\hline Donations & 162 & 69.8 \\
\hline Selling of signage & 142 & 61.2 \\
\hline Selling of sponsorship & 123 & 53.0 \\
\hline
\end{tabular}

The forms of pay-to-play funding not only took on slightly different names, but also vary widely in terms of structure. To generate a greater understanding of the disparity, school districts were asked to identify and describe their method of pay-to-play funding (see Table 2). Ninety-four schools reported they charged all student-athletes equal amounts regardless of sport type. Within those 94 schools, the mean cost to participate was $\$ 112.28$ with a standard deviation of $\$ 80.30$. In addition to the high standard deviation, the range of the data ( $\$ 15$ to $\$ 400)$, median (\$100), and mode (\$50) all suggest a high degree of variance among school districts.

Instead of charging all student-athletes a set amount, nine schools varied the amount depending on the sport played. For example, within one school district, ice hockey was the only sport requiring student-athletes to pay-to-play. Within another school district, all sports were the same cost except football. 
Finally, 31 school districts reported varying the amount they charged student-athletes based on the number of sports the student-athlete played. Common within these districts were "caps" placed on how much an individual student-athlete was charged and/or caps placed per family. One school even noted a difference in cost based on whether students were classified as regular, reduced, or free lunch recipients.

School districts also raise money using various methods that require student-athlete involvement. While these methods might not be as direct as having student-athletes pay to participate, they do require the student-athletes to generate money for the athletic department as a means to fund their team. Accordingly, $162(69.8 \%)$ school districts require student-athletes to generate a certain amount of "donations," $142(61.2 \%)$ school districts require the "selling of signage," and $123(53 \%)$ require the "selling of sponsorships" (see Table 2).

Table 2. Frequency Table of Ohio High School's Pay-to-Play Payment Form

\begin{tabular}{l|c|c}
\hline $\begin{array}{l}\text { If your district does use a pay-to-play/pay-to- } \\
\text { participate format, how is it structured? }\end{array}$ & Frequency & Percent \\
\hline We charge a set, equal amount for all sports & 94 & 40.5 \\
\hline We charge varying amounts depending on the sport & 9 & 3.9 \\
\hline $\begin{array}{l}\text { We charge varying amounts depending on the number of sports the } \\
\text { student-athlete plays }\end{array}$ & 31 & 13.4 \\
\hline
\end{tabular}

As a means to answer the final research question (i.e., "What policies and procedures are in place to potentially mitigate due process litigation?") respondents were asked if their school district had a formal disciplinary policy, and if they did to describe it. In total, 134 (58\%) school districts reported having a formal process to hear athletics disciplinary issues. Content analysis of the policies revealed four main themes: (1) Chain of Command; (2) Code of Conduct; (3) Disciplinary Board; and (4) Athletic Director.

The most common disciplinary procedure reported was a formal chain of command $(n=52)$. As respondent 20 stated, "Suspensions are issued by athletics director, if appealed, to building principal, if appealed again, to superintendent, if appealed again, to board of education." Respondent 163 noted a similar policy as the "athletic director assigns disciplinary action (and) if (the) parent/athlete disagrees with athletic director, they can appeal to principal."

School codes of conducts were also frequently cited procedures to deal with athletics disciplinary issues $(n=25)$. The codes varied widely among the schools, though. Some employed moderately structured codes as reflected in respondent 18 stating, "We have a Code of Conduct for all athletes. If a violation of the Code happens, it starts with the AD. If the issue is not resolved it moves to the principal, then the Super." Other schools utilized an extremely formalized code. For example, respondent 121 outlined a four-stage due process procedure:

1. When a sport specific infraction occurs, the coach has the responsibility to discipline the participant. If an athletic handbook infraction occurs, the coach or athletic director will have the responsibility to 
discipline the participant. 2. The coach and/or athletic director shall meet with the participant being disciplined and their parents ... 3. The participant shall be given the right to appeal the coach's decision to the athletic director. 4. The final authority to accept or deny the appeal shall be the responsibility of the principal ...

Disciplinary boards $(n=21)$ and athletic directors $(n=20)$ were also cited as a part of the formal disciplinary process. Within the survey, the respondents often linked the two. For example, respondent 12 noted the district had an "Appeals Board made up of two board members, Principal, Athletic Director, Assistant Athletic Director and 2 Head Coaches." Respondent 125 stated a similar policy, saying specifically, "We have a review panel made up of superintendent, principal(s), athletic director and maybe a head varsity coach. Decision of panel is final." Others schools forwent the use of a board and just had the athletic director issue discipline. As respondent 47 stated, "(The) Athletic Director hears any issues and issues a decision."

It is important to note all the disciplinary policies described by the survey participants were in compliance with OHSAA's bylaws. That is, OHSAA Bylaw 3-1-1 (2017) states, "The principal of the school shall be held primarily responsible in all matters pertaining to interscholastic athletics involving the school" ( $p$. 38). The bylaw goes on further to explain the principal does so by appointing, training, and being responsible for an athletic director. Furthermore, OHSAA Bylaw 4-5-1 (2017) in Section 5 titled "Conduct, Character, and Disciple" provides individual schools with the power to punish student-athletes as they deem appropriate. This bylaw states explicitly, "In matters pertaining to personal conduct in which athletic contests and their related activities are not involved, the school itself is to be the sole judge as to whether the student may participate in athletics" (p. 45).

\section{Discussion}

The current study sought to reassess whether high school student-athletes have a legitimate claim to due process protection and subsequently evaluate the present day risks posed by such claims to state athletic associations and high schools. Thus, to help bridge the gap between theoretical discussion and practical application, and as the issue varies by state (Siegrist et al., 2016), the study focused on gathering data from specific actors (i.e., high school athletic association and member school districts and schools) in the single state (i.e., Ohio). Focusing on potential legal liabilities related to the Due Process Clause of the Fourteenth Amendment, the results of the current study suggest the state athletic association of Ohio (i.e., OHSAA), and many of the school districts therein are susceptible to due process litigation. More specifically, OSHAA's mission statement and bylaws arguably establish a link between interscholastic athletics and education. This link is furthered in the multiple districts that allow students to receive academic credit for sports participation, specifically when no policy or procedure is in place to deal with disciplinary issues. Additionally, the common uses of various forms of pay-to-play arguably further create a property interest for student-athletes in interscholastic athletics, thus entitling them due process protection. 


\section{Link Between Athletic Participation and the Academic Process}

The verbiage used in OHSAA's mission statement and Bylaw 4, as was the case in Duffley v. New Hampshire Interscholastic Athletic Association, Inc. (1982), entwines athletics with the furtherance of the educational mission of OHSAA's member institutions. This can be seen in the notion that the mission of Ohio high school sports is to not only promote athletics as part of the educational experience but also promote education itself. Furthermore, OHSAA notes high school athletics within the state are structured around the mission and purpose of education-based activities, thus clarifying the intent to associate OHSAA athletics with academics. In doing so, OHSAA and its member institutions are arguably integrating athletics with a student's educational process.

Furthermore, by allowing academic credit for competing in interscholastic athletics, approximately half the high schools are further entangling athletics and education. This strengthens the argument for the need for constitutional protection for participants. However, not all schools are equally susceptible to litigation, as many schools stated they had formal procedures in place to afford athletes due process. Of the institutions that reported allowing students to receive academic credit for athletics participation, 37\% reported having no formal disciplinary policies or procedures for student-athletes. These schools are seemingly at the highest level of vulnerability for litigation.

As Goss v. Lopez (1975) established, attending high school is a governmentally created expectation, and thus a property interest exists in regards to education, and students are constitutionally guaranteed due process protection. Justice White noted specifically that this due process protection applies to all activities encompassing the "total educational process." The mission statement and bylaws of OHSAA, as well as the policy of affording academic credit for athletics participation within the state of Ohio, arguably places sports under the umbrella of the total educational process. Thus, it can be logically argued Ohio interscholastic student-athletes have a property interest in athletics and therefore procedural due process would be required prior to any significant deprivation of that property interest.

\section{Pay-to-Play Structure}

Exploring whether financial requirements for membership on a team creates a property interest requires an analysis of the Court's definition of a property interest. The United States Supreme Court in Board of Regents v. Roth (1972) carefully discussed this point. Specifically, it stated, "The Court has also made clear that the property interests protected by procedural due process extend well beyond actual ownership of real estate, chattels, or money" (Board of Regents v. Roth, 1972, p. 571). But that "(a person) must have more than a unilateral expectation of it. He must, instead, have a legitimate claim of entitlement to it" (Board of Regents v. Roth, 1972, p. 572). By requiring an athlete to pay, or fundraise, through administrative standards in order to be eligible to participate on the team, the school is arguably creating a legitimate claim of entitlement, beyond a unilateral expectation. 
It can be concluded athletes who have made a team and paid the required fee to be a member have a clearly implied promise of continuance on that team. To clarify, the athlete may still be suspended or removed from the team for a violation of team rules, standards, or other eligibility reasons; however, if a legitimate claim of entitlement exists, a property interest is present and therefore due process must be given prior to such deprivation. Within the state of Ohio, six different methods were found to be used that required students to provide money to the athletic department in exchange for being allowed on an athletic team and each respondent indicated employing at least one method.

In regards to the amount of money being paid, the strength of the argument for the property interest's existence may wane. If the fees are simply nominal processing fees or are very minimal, then no legitimate claim of entitlement may exist. For example, if a student pays \$20 in paperwork fees, while another school requires students pay $\$ 250$ per sport, the latter student has a stronger "claim of entitlement" to his or her place on the team (once he or she has made the team) to establish a property interest. Regardless, the level of entanglement when requiring athletes to pay-to-play rises, thus generating a stronger position for the athlete having more than a unilateral expectation to his or her place on the team.

Within the state of Ohio school districts, the issue of the amount charged to student-athletes to participate in sports is apt. While the majority of districts reported charging all students the same amount regardless of the sport, or the number of sports student-athletes participated in, the amount charged varied widely. The mean amount collected from student-athletes in those school districts (\$112.18) arguably rises above a mere processing fee; however, the range (\$15 to $\$ 400)$ and the mode (\$50) suggest many schools have not created a legitimate claim of entitlement. As there is such a degree of variance between the amounts charged, each school district should assess its labiality individually, again referring to the need to analyze each situation on a case-by-case basis, as is necessary for the law. Responding school districts that reported no disciplinary procedures ( 97 , or $42 \%$ of respondents) and charged a considerable amount, thus creating a claim to entitlement, should be specifically wary of potential due process claims.

\section{Practical Application and Recommendations}

As Yasser and Block (2008) noted in their discussion of due process protection for interscholastic student-athletes, "The Supreme Court has determined that due process interests can change with society, and one would be hard-pressed to find an area in education that has seen a more drastic transformation than high school athletics" (p. 30). Taking all factors into consideration, it would suit OHSAA to review (and potentially rewrite) bylaws and its mission statement. For example, simply adjusting the language and removing the phrase "provides educational opportunities" from OHSAA's mission would help avoid potential litigation in the future, as the claim that athletics are part of the total educational process would be weakened. Furthermore, individual high schools and school districts should examine their own athletic mission statements and make similar modifications to avoid the legal situations found in Florida High School Activities Association (1975), Albach (1976), and Duffley (1982). On the other hand, if the athletic associations and institutions believe in their missions as written, then it would 
suit them to formalize uniform disciplinary procedures prior to suspensions from athletics, to ensure they have provided a fair process prior to any deprivation.

To further weaken the claim that interscholastic athletics is a part of the educational process, Ohio school districts should reconsider whether or not they allow student-athletes to receive academic credit for athletics participation. They should also re-evaluate the use of the pay-to-play structure, as paying to participate creates a property interest and, thus, entitles participants to the right to due process. Considering both awarding academic credit and pay-to-play programs were found to occur at a high rate within Ohio, a majority of school districts may be increasingly vulnerable to ligation in cases where a student-athlete is suspended without due process.

It is further advised that within Ohio the method for handling disciplinary issues in sports be reviewed. Currently, OHSAA defers punishment for disciplinary issues to the individual schools (see Bylaw 3-1-1 and Bylaw 4-5-1). While the study found some schools have instituted adequate policies providing due process, a large percentage were found lacking in this area. An absence of such policies creates the potential for student-athletes to claim due process violations. Thus, it behooves institutions employing pay-to-play programs and/or permitting class credit for participation in athletics to establish due process procedures for athletics suspensions or expulsions, the same as if a student were being suspended or expelled from the classroom.

In closing, the value placed on athletics in today's society is no longer in line with the value afforded to student-athletes in the justice system. As the Supreme Court stated in Board of Regents v. Roth (1972), "the range of interests protected by procedural due process is not infinite" (p. 570); however, the varied judicial review and legitimacy of certain arguments supporting a liberty and/or property interest in sports, combined with the acknowledgment by multiple courts over the years that athletes may have a constitutional right to due process in certain instances, suggests student-athletes will continue to file lawsuits and seek due process.

\section{Limitations}

While the findings presented in the current study are valid, the results and implications are limited in a few ways. First, the population of Ohio high schools and OHSAA represented only the policies, procedures, and mission of a single state and its athletic association. As a result, the findings lack external validity. Future work is thus needed to test whether the findings hold true across the county.

Secondly, the legal analysis presented is based primarily on old case law. As due process protection for interscholastic student-athletes has not been ruled upon in recent years, the presence of recent legal precedent is lacking, thus making the arguments presented speculative. However, legal precedent has no expiration date, thus, regardless of the age of the case, it may still be used and cited by lawyers and judges when handling a case. Therefore, while more recent case law would strengthen the argument presented within the piece, the use of older court decisions does not jeopardize the findings and the potential implications to current-day high schools. 


\section{References}

About the OHSAA. (2017). The Ohio High School Athletic Association. Retrieved from http:// ohsaa.org/AboutOHSAA

Albach v. Odle, 531 F.2d 983 (1976).

Brady, E., \& Glier, R. (2004, July 29). To play sports, many U.S. students must pay. USA Today. Retrieved from http://usatoday30.usatoday.com/sports/preps/2004-07-29-pay-to-play_x.htm

Brentwood Academy v. Tenn. Secondary School Athl Assn, 531 US 288 (2001).

Board of Regents of State Colleges v. Roth, 408 U.S. 564 (1972).

Bruce v. S.C. High School League, 258 S.C. 546 (1972).

Burggraf, C., \& Rau, J. (2017). Interscholastic Athletics. Members Only, 132(16), 1-11.

Cook, B. (2012, August 20). Will 'pay to play' become a permanent part of school sports? Forbes. Retrieved from https://www.forbes.com/sites/bobcook/2012/08/22/will-pay-to-play-become-apermanent-part-of-school-sports/\#78f8bc57218b

Coleman, J. S. (1961). Athletics in high school. The Annals of the American Academy of Political and Social Science, 338, 33-43. https://doi.org/10.1177/000271626133800105

Creswell, J. W. (2009). Research design: Qualitative, quantitative, and mixed methods approaches. Los Angeles, CA: Sage.

Duffley v. New Hampshire Interscholastic Athletic Assoc., Inc., 122 N.H. 484 (1982).

Florida High School Activities Assoc., Inc. v. Bryant, 313 So. 2d 57 (1975).

Goss v. Lopez, 419 U.S. 565 (1975).

Green, L. (2017). 2016 sports law year-in-review. National Federation of State High School Associations. Retrieved from https://www.nfhs.org/articles/2016-sports-law-year-in-review/

Green, L. (2015). Top ten sport law issues impacting school athletics programs. National Federation of State High School Associations. Retrieved from https://www.nfhs.org/articles/top-tensports-law-issues-impacting-school-athletics-programs/

Hamilton v. Tenn. Secondary School Athl Assn, 552 F.2d 681 (1976).

Hudak, T. L. (2017). 100 years of the Ohio High School Athletic Association: A centennial moment. History of The OHSAA. Retrieved from http://ohsaa.org/about/history

Lincoln, Y. S., \& Guba, E. G. (1985). Naturalistic inquiry. Beverly Hills, CA: Sage. https://doi.org/10.1016/0147-1767(85)90062-8

Linder, D. (2015). Exploring constitutional conflicts. Exploring Constitutional Law. Retrieved from http://law2.umkc.edu/faculty/projects/ftrials/conlaw/proceduraldueprocess.html

Menke v. Ohio High School Athletic Association, 2 Ohio App.3d 244, 245 (1981).

Morrison, et al., v. Roberts, 82 P.2d 1023 (1938).

The National Federation of State High School Athletic Associations. (2017). 2016-17 high school athletics participation survey. Retrieved from http://www.nfhs.org/ParticipationStatistics/ PDF/2016-17_Participation_Survey_Results.pdf

NFHS. (2017). High school participation increases for 28th straight year, nears 8 million mark. National Federation of State High School Associations. Retrieved from https://www.nfhs.org/ articles/high-school-sports-participation-increases-for-28th-straight-year-nears-8-million$\underline{\text { mark } /}$

Niles v. University Interscholastic League, 715 F.2d 1027 (1983).

Ohio High School Athletic Association Bylaws. (2017, May). Retrieved from http://ohsaa.org/ Portals/0/About-the-OHSAA/Bylaws.pdf 
Ohio High School Athletic Association Regulations/Guidance on alcohol, tobacco, drugs and steroids. (2014). In Eligibility Guide for Participation in High School Athletics. Retrieved from http://www.ohsaa.org/eligibility/eligibilityguide.pdf

OHSAA mission and commitment. (2015). The Ohio High School Athletic Association. Retrieved from http://www.ohsaa.org/general/about/Mission.htm

Property; property interest. (n.d.). Legal Information Institute. Retrieved from https://www.law. cornell.edu/cfr/text/31/515.311

Siegrist, A., Czekanski, W. A., \& Silver, S. (2016). Interscholastic athletics and due process protection: Student-athletes continue to knock on the door of due process. Mississippi Sports Law Review, 6(1), 1-22.

U.S. Const. amend. XIV, $\S 1$.

Whipple v. Oregon Sch Activities Assn, 629 P.2d 384 (1981).

Wooten v. Pleasant Hope R-VI School District and Stout, 139 F. Supp. 2d 835 (2000).

Yasser, R., \& Block, M. (2008). Upon further review: Recognizing procedural due process rights for suspended high school athletes, Entertainment and Sports Law, 26(1), 22-35.

Yeung, R. (2015). Athletics, athletic leadership, and academic achievement. Education and Urban Society, 47(3), 361-387. https://doi.org/10.1177/0013124513495277

Zehner v. Central Berkshire Regional School District, 921 F. Supp. 850 (1995). 